\title{
The Combination of Full-time Teachers and Student Counselor in University Ideological and Political Course
}

\author{
Hongfeng CHENG \\ Wuhan University of Science and Technology College of Urban Construction Hubei Wuhan 430065
}

\begin{abstract}
Full-time teachers of ideological and political course together with student counselor are two main forces in university students' ideological and political education work, but in real work, the advantage of malposition of the two aspects fails to combine effectively, which to a large extent influences the pertinence and practicalness of university students' ideological and political course. Forming the join force of ideological and political teacher group along with the student counselor, setting up a scaffold, integrating the source, and interpenetrating are necessary requirements to strengthen and improve education effects of the university students' ideological and political course, as well as improve education and teaching level of ideological and political course, and also are effective means to enrich the effectiveness of university students' ideological and political education work.
\end{abstract}

KEYWORD: Ideological and Political Course; Full-time Teachers; Counselor; Combination

Ideological and political course is the main channel and main territory of university students' ideological and political education. It plays an important role in aspects such as leading the student to grow up healthily, and cultivating youthful students' proper outlook on the world, on life and on value. "To reach the aim of teaching and educating people, ideological and political course must put in time and energy on effectiveness, but the key to enhance the effectiveness is the construction of the teaching body." [1] In real work, the advantage of malposition of full-time teachers and counselors fail to combine effectively, and urgently wait to come into play further. Aiming at new change and challenges of current domestic and international situation, facing new condition and new problem the reform of universities are confronted with, along with new characteristics and requirements of youthful students' developing, the destiny of ideological and political course is heavier, the responsibility is larger, and the task is harder. Therefore, forming the join force of ideological and political teacher group along with the student counselor, setting up a scaffold, integrating the source, and interpenetrating appear much urgent and necessary, they are necessary requirements to strengthen and improve education effects of the university students' ideological and political course, and are also forceful move to further improve the effectiveness of university students' ideological ad political education work.

In recent years, especially after the carrying out of the " 05 program" of the university ideological and political course, administrative department for education and universities of various regions all attach much importance to the construction of the teacher body of the ideological and political course. Through ways of completion of the system, regulating the administration, enhancing the investment, strengthening the training and the like, the teacher body of the university ideological and political course has had a big improvement: the construction of the teacher body becomes more reasonable,; education level of the teacher has a obvious advance; the force of training increases further; the body's entire quality gets continuously improved.

To exert themselves to strengthen and improve the education and teaching of the university's ideological and political theoretical course, the Propaganda Department of the Central Committee of the CPC along with the Ministry of Education has successively issued two documents: "the proposal on further strengthening and improving the university's

Cheng Hongfeng, (1967.08-) male, Hengyang Hunan, the Han nationality, teacher of Wuhan University of Science and Technology, Lecturer, the research direction is ideological and political education. 
ideological and political theoretical course" and "the proposal on further strengthening the construction of the teacher body of the university's ideological and political course ". The two all explicitly emphasizes, "must continuously optimize and enrich the teacher body of the university's ideological and political course by following the principle of combing the full and the part." At the same time, they points out, "cadres of full-time ideological and political work together with the counselor who are qualified can take the responsibility of some certain education task of the ideological and political theory course." However, in fact, this work has not fulfilled completely, the organic combination of full-time teachers of the ideological and political theory course and the counselor has not formed, the effect of combined education has not appeared.

\section{THE URGENCY AND NECESSITY OF COMBING THE FULL-TIME TEACHERS WITH THE COUNSELOR}

The general work objective of the teacher of ideological and political course and the counselor are the same, they both take the outlook on life of educating the students systematically on ideology and politics, serving the students to become talents, and guide the students to set up proper outlook on the world, life, and value. But the two still exists some distinctiveness and difference in some specific work objectives. Full-time teachers usually focus on going on theoretical education abd the imparting of universal knowledge, but the counselor trends to aim at the students' learning and life reality, mainly develop freshmen's entrance education, psychology healthy education, aid the poor, the graduates' employment instruction and daily ideological and political education work, meanwhile instruct students to hold various activities of the organization of the Youth League which are beneficiary to health. The inconformity of the two in specific work objective leads to the lack of mutual support, and makes it difficult to form a mutually supportive education system.

Ideological and political courses such as "Basic Principles of Marxism", "Mao Zedong Thought, Deng Xiaoping Theory and "Thought of Three Represents",, "Outline of Chinese Modern History", "The Ideological and Moral Cultivation and Legal Basis" and the like are usually regarded as a unique classroom teaching curriculum in reality,. The whole teaching process of those courses lack the combination with students' real thoughts, has not been able to extend to students' real life and study, and also ignores its ideological and political features different from other major courses. Students counselor is university students' life instructor and intimate friends to grow healthily, their work is not only to "display their talent and preach the $1^{\text {st }}$ doubts", at the same time still need to help student in constructing a "meaningful world". But in real life, the counselor's daily work of ideological and political education appears more often in the form of "public administration", mainly dealing with affair work, though can help students solve much difficulties and problems in both the study and the life, but it is a question whether they can really help students deal with their misunderstanding and confusion on ideology and cognition, and help them construct their "meaningful world" in reality.

"In universities, the usual understanding is that the ideological and political theory course belong to the educational administration system, the counselor's work belong to students work system, but the educational administrative system and the student work system have different modes of operation, so teaching of the ideological and political course has no direct relationship with the counselor's work in practice" [2]. Because the lack of effective communication between the teacher of the ideological and political theory course and the counselor, and the lack of information sharing and cooperation between each other, advantage of each side does not realize a complementation, superimposed effects of the two groups cannot be fully expressed, ultimately making full-time teachers of the ideological and political theory course lack deep understanding of students' study, life and the condition of ideology, which makes the teaching of the theory disconnect from the reality; however, the counselor is involved in all kinds of complicated students affair, having no enough time to conduct system study if the theory, making the theory accomplishment of itself not improved and having the the work and the education of the ideology disconnected.

Obviously, the education of the ubiquitous ideological and political theory course and the daily ideological and political education exists the phenomenon of "two piece", which to a large extent influences the university student's effectiveness of work in ideological and political education. "From the aspect of the contingent of the ideological and political education, work of both the teacher of ideological and political course and the counselor appear choke points, being not able to find out effective breaking space, limiting the work activeness and innovativeness, indirectly affects the propelling of the ideological and political education work" [3]. Therefore, innovating the mechanism, making the full-time teacher of the university's ideological and political theory course organically combine with the students' counselor, expressing their join forces, not only do good to the in-depth implementation of the central authorities' politics and guidelines on university students' ideological and political education, but also do good to 
propelling the combination of the theory and practice, strengthening complementation of each other's advantages of the teacher body, feasibly enhancing the pertinence and effectiveness of the ideological and political education.

\section{APPROACHES TO COMBINE THE FULL- TIME TEACHER AND THE COUNSELOR}

\subsection{Set up a scaffold, and keep communication channels open}

Communication is an important content in modern Management Science; it has the function of passing on information, facilitating coordination, promoting the perspective-taking and enhancing the rally power. In all university work of imparting knowledge and educating people, management education, along with education through service, communication is a necessary and effective means. Education and teaching of the current ideological and political theory course lack pertinence, objectively, demanding more communication between the teacher and the counselor. The communication channel between the teacher of the ideological and political course and the counselor can be unimpeded though forms of carrying out the mutual teaching review, analyzing the classic case, holding the exchange and discuss on work experience, facilitating collective preparation of instruction and counselor's help to the class and the like. Helping the teacher feasibly know the student group's real needs, making design of the teaching content being closer to the student, the life, and the reality by intensive communication; and improving most youthful students' self-identity and satisfaction to the university ideological and political course step by step by continuously improving and perfecting the teaching design of the education of the ideological and political theory course. Meanwhile, as a counselor, requirements are to keep an eye on students' daily ideology condition, watch, collect and record students' evaluation and feedback idea in the ideological and political course by means of usual observation of the practice of education management so as to put forward idea and suggestions on improving teaching of the ideological and political course on their own angle. And can also indirectly serve the teaching reform of the ideological and political course by taking part in the carrying out of the course design of the theoretical and practical teaching.

\subsection{Integrating the resource and combining the research team of studies}

Usual problem in current ideological and political education are that teaching of the ideological and political theory course disconnects from the students' reality, leading the teaching effect not ideal; the society experience of the counselor body is insufficient, their theory accomplishments are enough, as well as being difficult in leading of students' ideology. "The character of applicability and practicality of the subject of ideological and political education decide that only by continuously facilitating the research of the subject of the ideological and political education can we give a forceful theoretical response to the continuous developing and changing practice of the ideological and political education, and only by putting the practice of the ideological and political education at the first place of the eyesight of the subject so as to go on the condensation and deliberation can we obtain regular recognition "[4]. Fully integrate the resource, make the teacher of the ideological and political theory course cooperate with the student counselor, and jointly go on study research and discussion on all kinds of problems in practice of the ideological and political education, will help the counselor promote improvement of the learning ability, and make up the shortage of theoretical accomplishment, make the daily work more effective; and also form favorable research atmosphere of team cooperation in the subject of ideological and political education, improve the level of theoretical and practical research, accumulate accomplishment fir the subject construction.

\subsection{Interpenetrating and innovating the education practice method}

The teacher of the ideological and political course can be part-time counselor of the student, taking part in university students' daily administration work, instructing students in participating in the society practice, having a hand in all kinds of after-class activities, and more directly and profoundly knowing students' ideology trend, learning situation and mental states by regularly deepening the communication with the student, hence to the benefit of making the teacher proceed from the reality of student and improve the quality and effect of the classroom teaching. Student counselor with certain basis and condition can be as the teaching assistant of the ideological and political theory course, knowing the ideological trends of the student, counselors objectively grasping the students' reality can be part-time teachers and take part in teaching discussion, and research of the ideological and political theory course, hence to the benefit of the teacher's surrounding the needs of the students in learning, living, mentality, and politics; shooting the arrow at the target have a definite object in view to carry out the theoretical teaching so as to enhance the pertinence and effectiveness of the classroom teaching. 


\section{REFERENCES}

[1] Sheng Haiying, Du Haiyan, Cao Yizhe. Problem and Countermeasure in Construction of the Teacher Body of University's Ideological and Political Theory Course. Liaoning Education Research, 2007(12).

[2] Yan Wanchun, Wu Bin, First Exploration on Interative Mode between the Teaching of the Ideological and Political Course and the Counselor. Journal of Sichuan
University of Science\& Engineering (social science edition), 2013(3).

[3] Qin Shujuan, Liang Cunning. Research on the Joint Education Mecvhanism between the teacher of the Ideological and Political Course and the Counselor. Ideological Theory Education, 2010(21).

[4] Yang Chengguang. USTB's Complementary of Advantages of Two Teams of Ideological Education. China Education Daily, 2009-12-07. 